\title{
National Identity after a Conflict: National Identity Choice among Northern Irish Youth
}

\author{
Natasha Bingham \\ Assistant Professor, Loyola University New Orleans, UsA \\ nbingham@loyno.edu \\ Christopher Duffy \\ Loyola University New Orleans, USA \\ phillyduff@gmail.com
}

\begin{abstract}
This work uses multinomial logistic regression to explore how Northern Irish youth view their national identity and the factors that shape their self-identification post1998 Good Friday Agreement. We use the 2005-2015 Northern Ireland Young Life and Times Surveys of 16-year-olds to investigate these questions. The results indicate that intergroup contact is less influential than environmental factors on national identity. Residential and school composition has more of an effect on solidifying Irish identity than British identity (relative to that of a Northern Irish identity). Our work adds to the literature on national identity development and choice among young adults in postconflict and post-peace-agreement environments.
\end{abstract}

\section{Keywords}

national identity - post-conflict nationalism - religion and nationalism - youth identity development - Northern Ireland

According to the 2011 census, the number of individuals who identified as Catholic was 45 per cent and those who identified as Protestant was 48 per cent (Northern Ireland Statistics and Research Agency 2011). However, 40 per cent of the population identified as British, 25 per cent as Irish, and 21 per cent as Northern Irish. The national identity question was absent from the 2001 
census when the religious breakdown was 44 per cent Catholic and 53 per cent Protestant (Northern Ireland Statistics and Research Agency 2001). Ed Cairns (1982) at the height of the conflict iterated that religious identity is salient to those that live in Northern Ireland. But recent data might point to another reality and repudiate to a degree the view that Protestants identify as British and Catholics identify as Irish. It seems that religion might be only one factor that shapes identity preference and that other factors might have become more salient in this post-conflict environment (McKeown 2013, p. 25).

In a post-Good Friday Agreement Northern Ireland, this work examines how young adults define their identity and the factors that shape identity preference in this new climate. The Good Friday Agreement that was formally signed on April 1998 put an official end to the Troubles. The Agreement memorialized the management of nationalist and unionist identities after decades of violent conflict while trying to address the economic, political, and cultural reasons behind the Troubles. The compromises (in regards to institutions, statutes, and formalities) contained within the Good Friday Agreement have shaped how individuals within communities see themselves. This work uses multinomial logistic regression to explore how Northern Irish youth view their national identity and the impact of intergroup contact and environmental factors on identity preference post-1998 Good Friday Agreement. We use the 2005-15 Northern Ireland Young Life and Times Surveys of 16-year-olds to investigate these questions. The results indicate that intergroup contact is less influential than environmental factors on national identity. Residential and school composition has more of an effect on solidifying Irish identity than British identity (relative to that of a Northern Irish identity). Our work adds to the literature on national identity development and choice among young adults in post-conflict and post- peace agreement environments, and in particular for Northern Ireland the saliency of the Northern Irish identity among Protestant/unionist and Catholic/nationalist youth.

\section{Northern Ireland and the Good Friday Agreement}

17 years after the implementation of the Good Friday Agreement, 91 per cent of people say relations between Catholics and Protestants are the same or better than they were five years ago and 86 per cent say it will improve or stay the same over the next five years (Northern Ireland Life and Times Survey 2015). The Good Friday Agreement was seen as a new chapter in Northern Ireland's history. The Agreement reshaped Northern Ireland's politics and in many ways is symbolic of the changes happening within communities on the 
ground. Political parties, Ulster Unionist Party (UUP) and Social Democratic and Labour Party (SDLP) that were influential to the implementation of the Good Friday Agreement lost electoral ground to perceived more radical counterparts Sinn Féin and Democratic Unionist Party (DUP). In 1998 on the onset of the Agreement the UUP and SDLP won roughly 43 per cent of the vote and the DUP and Sinn Féin won roughly 35 per cent (Scanlon 2008, p. 88). In 2016 the UUP and SDLP acquired only 24.6 per cent of the vote and the DUP and Sinn Féin 53.2 per cent (BBC News 2016). This political rearrangement began in 2002 because of internal divisions within the UUP over "its 'support' for the GFA, personal animosities and the continuing experience of electoral decline" and the retirement of senior personalities within the SDLP like John Hume and Seamus Mallon (Cochrane 2013, pp. 234-35) but the two parties that would emerge took advantage of the post-Good Friday Agreement political context. Despite fears that two long diametrically opposed entities would lead to the collapse of the Agreement, instead a functioning coalition exist between the two and has forced some moderation in their policies.

It was the hope that this Agreement and political moderation would usher in an era of equality and compromise in Northern Ireland after 30 plus years of violent, sectarian conflict. One of the principal goals of the Good Friday Agreement was to establish a parity of esteem in Northern Ireland, the idea that both communities were coequal members of society. According to Michelle Scanlon, "Parity of esteem in Northern Ireland is understood to be the equal legal recognition and protection of the identities of the two dominant ethno-national groups" (Scanlon 2008, p. 79). Part of the Agreement ensured the equal participation of both communities in the political process: a 108-member legislative assembly elected via proportional representation-single transferable vote (PR-STV) to reduce feelings of disenfranchisement among the populace, parallel consent or weighted majority voting for all legislation to ensure cross-community support and transparency, and joint election of the Executive (First Minister and Deputy First Minister) on a cross-community basis (Good Friday Agreement 1998). Another aspect of the Agreement ensured the protection of individual rights and liberties of those in both communities, the "commitment to the mutual respect, the civil rights and the religious liberties of everyone in the community" (Good Friday Agreement 1998). This commitment was enshrined in the Human Rights Commission, the Equality Commission, the Policing Commission, and a number of socioeconomic and sociocultural statutes to combat the problems that originally led to the Troubles (i.e., a body to investigate complaints of discrimination, a police force composed of 50/50 Catholics and Protestants, and the ability of Northern Irish citizens to hold British, Irish or both passports). 
Despite the hopes of the institutions, statutes, and stipulations within the Agreement challenges persist. Two of the matters that inflamed the conflict, policing and criminal justice remain contentious to this day. Institutions such as the Police Service of Northern Ireland (PSNI) remain majority Protestant. The PSNI statistics show that for 201667 per cent of police officers are "perceived Protestant" and $3_{1}$ per cent are "perceived Catholic" (PSNI 2016). One of the stipulations of the Good Friday Agreement was the creation of a police force that represented the diversity of Northern Ireland and its communities. The PSNI was "to be representative in terms of the make-up of the community as a whole ...." (Good Friday Agreement 1998). The lack of diversity within the PSNI reignited discussions about whether the 50/50 policy of Catholic/ nationalist and Protestant/unionist recruitment should be reintroduced (McAleese 2015). Early prisoner releases of loyalists and republicans convicted of crimes during the 30-year conflict sparked outrage among individuals in both communities. Families of victims of republican and loyalist violence rejected the early prisoner releases and instead saw these releases as a lack of justice for the families and lack of punishment for the perpetrators of violence (The Guardian 2000).

The idea behind parity of esteem was that both sides would achieve equal gains (and losses) but the actuality is more interest is focused on the community's gains (and losses) of one's community vis-à-vis the other. While only half of unionists supported the Agreement, it was almost universally embraced within the nationalist community. Nationalists and unionists view the Good Friday Agreement through different prisms. Orla Muldoon, Karen Trew Jennifer Todd, Nathalie Rougier, and Katrina McLaughlin (2007) highlight that Catholics identified more as Irish and Protestants as British; and both communities embraced the customs and traditions endemic of those communities. "The Belfast Agreement has failed to overcome Northern Ireland's intercommunal competitive dynamic" (Mac Ginty and du Toit 2007). For nationalists, the Agreement was seen either as a step toward a united Ireland or the acquisition of rights previously denied and a seat at the political table at Stormont after decades as an oppressed minority. For unionists, the Agreement represented an erosion of culture, in particular their British identity with restrictions on parading and "The Twelfth" celebrations, and the constitutional status of Northern Ireland within the United Kingdom (Cochrane 2013, p. 201). In 2015, the Northern Irish Life and Times Survey reported that in 199845 per cent identified as unionist compared to 25 per cent as nationalist and while the nationalist number has remained the same the unionist percentage is down to 33 per cent. These trends might create unease within the unionist community as the Good Friday Agreement stipulates that 
Northern Ireland remains a part of the United Kingdom as long as the majority of the population vote in favor of such a constitutional arrangement (Good Friday Agreement 1998). Demographic change as well as strong feelings among unionists that Britain has been disinterested in Northern Ireland and its inhabitants since the Agreement has led to a fading sociocultural identity within the Protestant population (O'Toole 2013). These events have greatly altered Protestant/unionist opinion of the Agreement in comparison with their Catholic/nationalist counterparts. In 199841 per cent of unionists believed that the Agreement was equal for both unionists and nationalists and 50 per cent believed nationalists benefited, by 200318 per cent believed it to be equal and 70 percent believed the Agreement favored nationalists. By contrast, of nationalists in 199873 per cent believed the Agreement benefited both communities equally and in 2003 that number dropped to $5^{\circ}$ per cent (Mac Ginty and du Toit 2007). The decline in support for the Agreement among both communities is representative of the inability of the Good Friday Agreement to solve some of Northern Ireland's enduring problems- paramilitary violence, sectarian anger, and controversies over marching season (to name a few) (Cochrane 2013, p. 213).

\section{Theoretical Framework}

History impacts the identities of young adults in Northern Ireland. Siobhán McAlister, Deena Haydon, and Phil Scraton (2013) state "decades of violence, displacement and population movement have consolidated the historical relationship between place, identity and violence in Northern Ireland. Not only neighborhoods, but entire areas of towns and cities remain synonymous with either the Catholic or Protestant tradition" (p. 3). Northern Ireland's history has been retold to the youth through families, school curriculum, churches, murals, and the media and internalized, impacting their perceptions of their communities and themselves. At the same time, economic, political, and cultural matters that originate after the Troubles and the Good Friday Agreement also affect their identities. The 16-year olds in the sample have had to contend with the uncertainty and instability of the times - paramilitary violence, paramilitary ceasefires, the passage of the Good Friday Agreement, the return of devolved government, the suspension of that government in 2002, the St. Andrews Agreement, a return of the power-sharing Executive in 2007; and the first full legislative session in 40 plus years (2007-11). So in many ways, their lives and their communities are still affected by the legacy of sectarianism and violence. 
National identity is one form of social identity. During childhood and adolescence, social identity development is central to those formative years. In Northern Ireland, previous research shows that children grasp sectarian divides at a young age. By the age of three, $5^{1}$ percent can identify one sectarian symbol (Ewart and Schubotz 2004) and by six, go percent knew of the divide, 33 percent identified with a side and 15 percent were "making sectarian comments" (Gallagher and Cairns 2011). Extensive stereotypes are formed by ten or 11 years about the 'other's' entire way of life (Barrett and Oppenheimer 2011). 11 years of age is when young people begin to discern their group membership based on where they live, where they go to school, their first and last names, their appearance, and their speech (Cairns 1982; McAlister, Haydon, and Scraton 2013). Henri Tajfel (1972) defines social identity as "the individual's knowledge that he belongs to certain social groups together with some emotional and value significance to him of the group membership" (Hogg 2001, p. 186). Group status is internalized; individuals desire to improve their group's status because by extension it improves their individual status (Tajfel and Turner 1986). Positive traits are then bestowed upon the in-group and negative ones on out-groups (Tajfel and Turner, 1986 Taylor and Moghaddam 1994, p. 61; Turner et al. 1994).

Intergroup contact can shape perceptions of both the in-group and outgroups. Intergroup contact has two forms: individual behavior (contact) and context. This paper argues youth that have no exposure to different communities are less likely to adopt a Northern Irish identity, making British and Irish identities more frozen. The first to advance the social contact hypothesis is Gordon Allport (1954) who states that interpersonal contact among members of different out-groups leads to a reduction in prejudicial views conditional on: 1) the groups having equal status; 2) each striving for a common goal; 3) intergroup cooperation; 4) and that contact between groups is met with acceptance from the greater society. More contact with diverse individuals and groups will produce more tolerant and positive attitudes about others. Thomas Pettigrew and Linda Tropp (2006) elaborate on the social contact hypothesis. Through their meta-analysis, the authors find that intergroup contact reduces intergroup prejudice and greater contact reduces hostility. The authors further find that though Allport's four conditions bolster the positive effects of intergroup contact, they are not essential for positive outcomes to occur.

Institutions reproduce and reinforce ethno-national identities in Northern Ireland (Byrne, Conway, and Ostermeyer 2005; McAlister, Scraton, and Haydon 2009; McGrellis 2010). One of those institutions is school. Ernest Gellner (1983) asserts that "the culture in which one has been taught to communicate becomes the core of one's identity" (p. 61). While the family is viewed as the 
primary agent of socialization, schools are seen as significant secondary ones. Since the 1930s, a de-facto segregated school system has existed in Northern Ireland- state (controlled) schools for Protestants and Catholic (maintained) schools for Catholics. The Northern Ireland Council for Integrated Education (NICIE) was established in 1987, and the first integrated school, Lagan College, was established in 1981 after the failure of existing schools to accept the integration ethos encapsulated in the 1978 Education Act. Almost 22,000 or seven per cent attended integrated schools in the 2014-15 school year (Department of Education of Northern Ireland 2015). The study of national history begins in the first three years of secondary school between the ages of 11 and 14 with a standard curriculum for all students despite the type of school attended or their religion. The history curriculum attempts to provide balance to Northern Ireland's history, removing it from its sectarian enclaves and placing it in the large context of European and world history (Barton and McCully 2005). Bernadette Hayes, Ian McAllister, and Lizanne Dowds (2007) find Protestants that attend integrated schools are more likely to adopt more neutral identity patterns and reject the traditional British/Unionist identity, while Catholics were more likely to abandon an Irish/Nationalist identity. Young adults were less concerned with continued union with the UK or the prospect of a united Ireland. Bernadette Hayes and Ian McAllister (2009) find that there is a small and growing population within the Catholic community that attends integrated schools. This might indicate that young Catholics might be more inclined to identify with a Northern Irish identity than their Protestant counterparts over time. The authors further discover that attendance at integrated schools increased cross-community contact throughout adulthood. Another institution that reproduces and reinforces ethno-national identities is the media. Karen Trew, Orla Muldoon, Gary McKeown, and Katrina McLaughlin (2009) show that post-1989, 63 percent of young people get their information on historical events through the media. The media tends to sensationalize all crimes to be political or religious, relating all crimes back to the Troubles and hyping the Troubles' influence on contemporary life (Ewart and Schubotz 2004).

Contextual effects such as environmental and sociocultural factors can influence identity choice. Environmental factors can include demographics of one's neighborhood, the composition of one's city such as population size and unemployment rate, and perception of relations between communities. Much of the literature on contextual effects has examined black-white relations, and in particular the impact of neighborhood composition on racial attitudes. Thomas Pettigrew (1959) conducted one of the earliest studies that stressed that the size of the local black population was directly correlated to 
the prejudice of white Southerners. Hubert Blalock's (1967) power threat hypothesis contends that as the size of the minority group increases, so do feelings of threat among the majority group - threat in terms of economic and political power. Census data show that the Catholic/nationalist community is growing at a faster rate than the Protestant/unionist community. Hayes and McAllister (2009) find that the political changes that accompanied the Good Friday Agreement increased insecurity among Protestants, "particularly the young" (p. 400). Even among young adults gains for the minority are often seen as coming at the expense of the majority. The authors state that "growing levels of disillusionment and feelings of insecurity among Protestants help to explain the increasing endorsement of a Northern Irish identity, particularly among the young" (Hayes and McAllister 2009, p. 400).

Previous research suggests that social environments affect the salience of racial identity (Gurin, Miller, and Gurin 1980; Welch, Sigelman, Bledsoe, and Combs 2001). Whites' geographic proximity to large populations of racial and ethnic minorities triggers perceptions of threat and negative feelings toward racial and ethnic minorities (Giles and Evans 1985; Glaser 1994). Siobhán McEvoy (2000) states: "like their elders, all young people do not have the same experiences of the conflict; their involvement and the severity of their experiences in large part depend on where they live and their socio-economic status (Cairns 1987). But all do grow up in heavily militarized and highly segregated ecologies" (p. 9o). Young people stated that their families pass down collective stories of the Troubles, in particular how the violence of the Troubles affected their communities and how their communities were involved in the violence (McAlister, Haydon, and Scraton 2013). "Stories passed down in families and communities, or through murals, memorials and commemorations, acted as continuous reminders of the past, and of the impact of the Conflict on "their community"” (p. 7). Environment can weaken or strengthen ethno-national identification (Harris 1995). This work expects that young adults that live in non-integrated neighborhoods and attend non-integrated schools, and perceive relations to be worsening between the two communities to have solidified British and Irish identities. As young people enter adolescence, they begin to realize the factors that are influential to their cultural identity - their neighborhoods, their schools, their sporting and leisure activities, their dress, and so on. According to Gallagher and Cairns (2011) study, the effects of early influences have a lasting impact on youth. These effects remain even after the first year of university (Cassidy and Trew 2004). The authors find there was very little change in young adults' national identity preferences post-adolescence, making the case that identity is solidified in adolescence. 


\section{Data and Methodology}

Data comes from the Northern Ireland Young Life and Times Survey. Initiated in 1998, the Young Life and Times Survey is a nationally representative survey of Northern Irish adolescents conducted annually by Queen's University Belfast and Ulster University. ${ }^{1}$ The purpose of the survey was to complement the Adult Life and Times Survey, and its rationale is to monitor the attitudes of young people and to ascertain their views on a wide range of social issues, such as community relations, politics, sectarianism, education, and just overall teenage concerns without parental input. This work analyzes the years of 200515 to assess how young adults identify and the factors that shape their identity preferences. $^{2}$ The total number of respondents is 11,861 total; the lowest was 625 in 2007 and the highest was 1,934 in 2014. ${ }^{3}$ The young adults in the survey sample were born as early as 1989 and as late as 1999 .

We use multinomial logistic regression to analyze our dependent variable. Multinomial logistic regression is used when there is a nominal dependent variable with three or more categories and no intrinsic order exist in the responses. Our dependent variable is the survey question: "Which of these best describes the way you think of yourself?" The options are: "British, Irish, Ulster, Northern Irish, Other". This variable is recoded with only three options: British, Irish, and Northern Irish. It is these three identity categories that are at the heart of the analysis, and this question gets at how essential national identity is to the social identity development of adolescents. The interpretation of results follows that of binary logistic regression. "Accordingly, the baseline and model log-likelihood values, the chi-square statistics, and the pseudo-variance explained measures have similar interpretations in multinomial as in binary logistic regression, except that they apply to models with more than two categories of the dependent variable" (Pampel 2000, pp. 69-70). This type of regression chooses one of the categories of the variable as a baseline and calculates the odds of the other possible outcomes relative to it; in this case the baseline

1 The survey sample for the Northern Ireland Young Life and Times Survey is drawn from the Child Benefit Register in Northern Ireland.

2 This work begins with 2005 in order for the results to be uniformed; prior to 2003 the sample consisted of 12-17 year olds and after 2003 the sample is solely of 16-year olds. It was only in the year 2005 that the survey asked the question about the family's financial well-being which this paper believes is an important variable to analyze to assess the influence of socioeconomic status on national identity preference.

3 Missing data was removed from the analysis. 
is Northern Irish identity and the likelihood of choosing a British or Irish identity is compared to it.

The independent variables examine the effects of intergroup contact and contextual effects. We use the survey question about participation in extracurricular activities: "How often do you socialize or play sport with people from a different religious community to yourself? 1) Very often, 2) Sometimes, 3) Rarely, 4) Never, 5) Don't Know"4 to assess intergroup contact. We analyze the effect of education, in particular the demographic composition of the respondents' school. "Would you describe your school as ...1) All or nearly all Protestant, 2) All or nearly all Catholic, 3) Mostly Protestant, 4) Mostly Catholic, 5) About half Protestant and half Catholic, and Don't Know." Another environmental variable we examine is neighborhood composition. "Would you describe you area as ... 1) Mainly Catholic, 2) Mainly Protestant, 3) Mixed, 4) Don't Know."5 The last environmental variable we explore is relations between the two communities. "What about relations between Protestants and Catholics? Would you say they are better than they were 5 years ago, worse, or about the same now as then? 1) Better, 2) Worse, 3) About the same, 4) Other."

In this work, we include several control measures. Age is of course one control variable; the respondents in the sample are all 16-years-old. Other variables included are sex (male or female), religion (Protestant, Catholic, or non affiliation), and family's socioeconomic status (not at all well off, not very well off, average, well off, or very well off). ${ }^{6}$ Based on previous research, we believe age, sex, religious affiliation, and socioeconomic status influence social identity development.

\section{Analysis}

Before we delve into the multinomial logistic regression in Table 1, we display summary statistics of the dependent, independent, and control variables in Table 2. Females are overrepresented in the sample, averaging about 60 per cent of the respondents. 39 to 42 per cent of respondents in the Northern

4 This question is missing from the 2006, 2008, and 2010 surveys. We used the question that asked about socializing with different religious communities and not ethnic communities.

5 We decided to exclude questions about living near the Peace Lines because these questions were first asked only in the 2014 survey. We also excluded the question on riots and sectarian violence in neighborhoods because this question was only asked in the 2013 survey.

6 Each of the variables was recoded to remove the "Don't Know" or "Other" categories from the analysis. 
TABLE 1 Multinomial logistic regression results

\begin{tabular}{llllll}
\hline National Identity $[\mathrm{a}]$ & 2005 & 2006 & 2007 & 2008 & 2009
\end{tabular}

\section{British}

$\begin{array}{lccccc}\text { Intercept } \beta & -0.251 & 0.078 & -0.924 & 0.601 & -0.043 \\ \text { Intercept S.E. } & (0.876) & (0.618) & (0.806) & (0.549) & (0.581) \\ & & & & & \\ \text { SES } & -0.078 & -0.248^{*} & 0.033 & -\mathbf{0 . 2 2 8} 8^{*} & -0.065 \\ & (0.197) & (0.156) & (0.187) & (0.14) & (0.137)\end{array}$

\begin{tabular}{|c|c|c|c|c|c|}
\hline CONTACT & 0.165 & - $[\mathrm{c}]$ & $0.371^{* * *}$ & - & -0.20 \\
\hline & (o.143) & & (0.143) & & \\
\hline
\end{tabular}

$\begin{array}{llllll}\text { Male } & -0.69 & -0.119 & -0.456^{*} & 0.109 & 0.008 \\ & (0.300) & (0.253) & (0.276) & (0.221) & (0.232) \\ \text { Female }^{[b]} & 0 & 0 & 0 & 0 & 0\end{array}$

$\begin{array}{lcclcc}\text { Catholic } & \mathbf{- 1 . 1 3 6 ^ { * }} & -0.005 & -0.337 & 0.066 & 0.015 \\ \quad \text { RES } & (0.665) & (0.519) & (0.553) & (0.428) & (0.433) \\ \text { Protestant } & 0.302 & 0.371 & -\mathbf{0 . 6 2 6 * *} & 0.030 & 0.055 \\ \quad \text { RES } & (0.331) & (0.303) & (0.314) & (0.234) & (0.249) \\ \text { Mixed RES }^{[b]} & 0 & 0 & 0 & 0 & 0\end{array}$

$\begin{array}{cccccc}\text { Protestant } & 0.613 & 0.503 & -0.020 & 0.220 & 0.310 \\ \text { SCH } & (0.520) & (0.378) & (0.423) & (0.295) & (0.306)\end{array}$

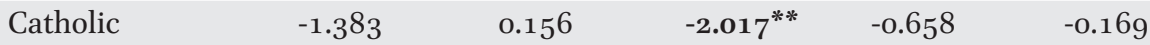

\begin{tabular}{|c|c|}
\hline $\mathrm{SCH}$ & (o.989) \\
\hline
\end{tabular}

$\begin{array}{lcllll}\text { M. Protestant } & 0.153 & 0.438 & -0.081 & 0.302 & -0.255 \\ \text { SCH } & (0.538) & (0.401) & (0.434) & (0.319) & (0.325) \\ \text { M. Catholic } & 0.374 & -0.395 & -0.840 & -1.522 & 0.462 \\ \quad \text { SCH } & (1.285) & (0.887) & (0.924) & (1.119) & (0.590) \\ \text { Mixed SCH }^{[\mathrm{b}]} & 0 & 0 & 0 & 0 & 0\end{array}$

$\begin{array}{lccccc}\text { Better RELS } & -0.421 & 0.024 & \mathbf{0 . 4 8 6 *} & -0.271 & -0.066 \\ & (0.320) & (0.273) & (0.310) & (0.243) & (0.236) \\ \text { Worse RELS } & 0.079 & -0.124 & 0.913 & 0.078 & \mathbf{1 . 0 0 3}^{\text {** }} \\ & (0.455) & (0.378) & (0.515) & (0.574) & (0.447)\end{array}$

$\begin{array}{llllll}\text { Same RELS } & {[\mathrm{b}]} & 0 & 0 & 0 & 0\end{array}$




\begin{tabular}{|c|c|c|c|c|c|}
\hline 2010 & 2011 & 2012 & 2013 & 2014 & 2015 \\
\hline 0.277 & 0.103 & -0.379 & $-0.972^{* *}$ & -0.419 & 0.012 \\
\hline$(0.572)$ & $\left(0.55^{\circ}\right)$ & $\left(0.5^{88}\right)$ & $(0.466)$ & $(0.422)$ & $\left(0.5^{26}\right)$ \\
\hline-0.009 & -0.135 & -0.084 & 0.112 & -0.118 & $-0.239^{*}$ \\
\hline$(0.145)$ & $(0.126)$ & $(0.131)$ & $(0.111)$ & (o.097) & $(0.126)$ \\
\hline \multirow[t]{2}{*}{ - } & 0.110 & $0.199^{*}$ & $0.185^{* *}$ & $0.120^{*}$ & 0.097 \\
\hline & $(0.08)$ & $(0.111)$ & $(0.90)$ & $(0.073)$ & $(0.105)$ \\
\hline-0.103 & 0.117 & $0.356^{*}$ & 0.149 & 0.131 & $0.509^{* * *}$ \\
\hline$(0.237)$ & $(0.191)$ & $(0.216)$ & $(0.178)$ & $(0.157)$ & $(0.202)$ \\
\hline o & o & o & o & o & o \\
\hline$-1.600^{* * *}$ & -0.504 & -0.417 & -0.257 & -0.403 & -0.530 \\
\hline$(0.546)$ & $(0.345)$ & $(0.380)$ & $(0.351)$ & $(0.324)$ & $(0.417)$ \\
\hline-0.321 & -0.142 & 0.268 & 0.226 & $0.344^{* *}$ & 0.009 \\
\hline$(0.247)$ & $(0.214)$ & $\left(0.23^{8}\right)$ & $(0.196)$ & $(0.172)$ & $(0.215)$ \\
\hline o & o & o & o & o & o \\
\hline 0.003 & -0.194 & 0.172 & 0.073 & 0.219 & 0.325 \\
\hline$(0.308)$ & $(0.265)$ & $(0.313)$ & $\left(0.25^{0}\right)$ & $(0.224)$ & $(0.284)$ \\
\hline-0.590 & -0.492 & -0.149 & $-0.861^{* *}$ & $-1.243^{* * *}$ & $-1.010^{*}$ \\
\hline$(0.626)$ & $(0.445)$ & $(0.541)$ & (0.419) & $(0.418)$ & $(0.532)$ \\
\hline 0.026 & -0.311 & -0.127 & -0.206 & -0.084 & -0.195 \\
\hline$(0.337)$ & $(0.281)$ & $(0.322)$ & $(0.250)$ & $(0.214)$ & $(0.277)$ \\
\hline-0.434 & 0.080 & -0.162 & -0.305 & -0.440 & 0.113 \\
\hline$(1.016)$ & $\left(0.5^{8} 3\right)$ & (o.657) & $\left(0.5^{26}\right)$ & $(0.413)$ & $(0.674)$ \\
\hline o & o & o & o & o & o \\
\hline-0.320 & 0.003 & -0.127 & 0.259 & 0.003 & 0.043 \\
\hline$\left(0.25^{2}\right)$ & $(0.207)$ & $(0.222)$ & $(0.187)$ & $(0.162)$ & $(0.211)$ \\
\hline 0.279 & 0.078 & 0.595 & $0.498^{*}$ & -0.188 & 0.253 \\
\hline$(0.431)$ & $(0.437)$ & $(0.535)$ & $(0.288)$ & $(0.325)$ & $\left(0.43^{8}\right)$ \\
\hline o & o & o & o & o & o \\
\hline
\end{tabular}


TABLE 1 Multinomial logistic regression results (cont.)

\begin{tabular}{lccccc}
\hline National Identity[a] & 2005 & 2006 & 2007 & 2008 & 2009 \\
\hline Catholic & -0.346 & $\mathbf{- 2 . 5 6 6 ^ { * * * }}$ & $\mathbf{- 1 . 2 0 0 ^ { * }}$ & $\mathbf{- 1 . 4 7 \mathbf { 1 } ^ { * * * }}$ & $\mathbf{- 0 . 7 8 9 ^ { * }}$ \\
& $(0.882)$ & $(0.880)$ & $(0.66)$ & $(0.532)$ & $(0.473)$ \\
Protestant & 0.398 & 0.234 & 0.369 & 0.235 & 0.292 \\
& $(0.426)$ & $(0.323)$ & $(0.326)$ & $(0.277)$ & $(0.271)$ \\
No Religion $^{[b]}$ & 0 & 0 & 0 & 0 & 0
\end{tabular}

Irish

\begin{tabular}{|c|c|c|c|c|c|}
\hline Intercept $\beta$ & 0.046 & $-1.509^{* *}$ & -0.817 & $-1.287^{*}$ & -1.084 \\
\hline Intercept s.E. & (o.990) & (0.730) & (o.886) & $(0.692)$ & $(0.747)$ \\
\hline \multirow[t]{2}{*}{ SES } & 0.068 & $0.267^{*}$ & -0.202 & 0.187 & 0.085 \\
\hline & $(0.182)$ & (o.169) & $(0.207)$ & $(0.165)$ & $(0.172)$ \\
\hline \multirow[t]{2}{*}{ CONTACT } & 0.034 & - & 0.142 & - & $-0.275^{* *}$ \\
\hline & $(0.148)$ & & $\left(0.15^{8}\right)$ & & $(0.135)$ \\
\hline \multirow[t]{2}{*}{ Male } & 0.284 & -0.141 & 0.345 & 0.266 & 0.426 \\
\hline & $(0.317)$ & $(0.304)$ & $(0.329)$ & $(0.260)$ & $(0.278)$ \\
\hline
\end{tabular}

Female $^{[b]}$

o

o

o

o

o

\begin{tabular}{|c|c|c|c|c|c|}
\hline Catholic & 0.437 & $0.795^{* *}$ & $0.725^{* *}$ & $0.488^{*}$ & $1.001^{* * *}$ \\
\hline RES & $(0.354)$ & $(0.327)$ & $(0.368)$ & $(0.296)$ & $(0.312)$ \\
\hline Protestant & $-1.006^{*}$ & -0.481 & $-0.93^{* *}$ & -0.265 & -0.123 \\
\hline RES & $(0.573)$ & $(0.443)$ & $(0.438)$ & $(0.388)$ & $(0.425)$ \\
\hline Mixed RES ${ }^{[b]}$ & o & o & o & o & o \\
\hline Protestant & $-2.512^{* *}$ & $-2.321^{* *}$ & $-0.45^{6}$ & $-1.563^{* * *}$ & -0.349 \\
\hline $\mathrm{SCH}$ & $(1.192)$ & $(1.109)$ & $(0.728)$ & $(0.555)$ & $(0.634)$ \\
\hline Catholic & $-0.5^{86}$ & $0.869^{*}$ & $1.314^{* * *}$ & $1.219^{* * *}$ & $1.184^{* * *}$ \\
\hline $\mathrm{SCH}$ & $(0.747)$ & $(0.457)$ & $(0.517)$ & $(0.342)$ & $(0.426)$ \\
\hline M. Protestant & $-2.169^{* *}$ & -0.087 & 0.043 & $-1.122^{* *}$ & -0.488 \\
\hline $\mathrm{SCH}$ & $(0.993)$ & $\left(0.5^{89}\right)$ & $(0.597)$ & $\left(0.5^{15}\right)$ & (o.6og) \\
\hline M. Catholic & -1.244 & 0.714 & 0.236 & 0.632 & 0.612 \\
\hline $\mathrm{SCH}$ & $(0.916)$ & (o.619) & $(0.720)$ & $(0.532)$ & $(0.591)$ \\
\hline
\end{tabular}




\begin{tabular}{|c|c|c|c|c|c|}
\hline 2010 & 2011 & 2012 & 2013 & 2014 & 2015 \\
\hline-0.573 & $-1.114^{* * *}$ & $-1.43^{* * *}$ & $-0.825^{* *}$ & $-0.737^{* *}$ & $-1.749^{* * *}$ \\
\hline$(0.569)$ & $(0.417)$ & $(0.522)$ & (o.377) & (o.330) & $(0.543)$ \\
\hline $0.473^{*}$ & $0.507^{* *}$ & $0.580^{* *}$ & 0.201 & $0.703^{* * *}$ & 0.137 \\
\hline$(0.287)$ & $(0.254)$ & $(0.302)$ & $(0.206)$ & $(0.170)$ & $(0.215)$ \\
\hline o & o & o & o & o & o \\
\hline 0.177 & $-1.868^{* * *}$ & $-1.363^{*}$ & $-1.419^{* *}$ & -0.272 & $-2.095^{* * *}$ \\
\hline$(0.718)$ & (o.693) & $(0.723)$ & $\left(0.5^{28}\right)$ & $(0.478)$ & (o.624) \\
\hline 0.077 & $0.33^{* *}$ & 0.025 & 0.077 & -0.130 & 0.205 \\
\hline (o.179) & $(0.148)$ & $(0.155)$ & $(0.124)$ & $(0.106)$ & $(0.145)$ \\
\hline - & 0.093 & 0.103 & 0.155 & -0.127 & $0.230^{* *}$ \\
\hline & (0.109) & $(0.127)$ & $(0.108)$ & (0.087) & $(0.118)$ \\
\hline 0.436 & 0.324 & 0.275 & 0.132 & 0.196 & -0.261 \\
\hline$(0.304)$ & $(0.221)$ & $(0.252)$ & $(0.215)$ & (o.18o) & $(0.228)$ \\
\hline o & o & o & o & o & o \\
\hline 0.018 & $0.563^{*}$ & $0.647^{* *}$ & $0.93^{* * *}$ & $0.976^{* * *}$ & $0.897^{* * *}$ \\
\hline$(0.328)$ & $(0.239)$ & $(0.275)$ & $(0.242)$ & (0.195) & $(0.247)$ \\
\hline$-0.929^{* *}$ & $-1.098^{* * *}$ & 0.254 & -0.235 & $-0.765^{* * *}$ & -0.541 \\
\hline$(0.435)$ & $(0.377)$ & $(0.421)$ & (o.333) & $(0.275)$ & $(0.395)$ \\
\hline o & o & o & o & o & o \\
\hline$-2.828^{* * *}$ & $-1.080^{*}$ & -21.297 & $-1.187^{* *}$ & $-0.692^{*}$ & $-1.483^{* *}$ \\
\hline$(1.094)$ & (o.6o6) & $(0.000)$ & $(0.500)$ & $\left(0.43^{8}\right)$ & (o.683) \\
\hline $0.921 * *$ & $0.55^{6}$ & $0.755^{*}$ & $0.659^{* *}$ & $1.057^{* * *}$ & $0.974^{* * *}$ \\
\hline$(0.418)$ & $(0.365)$ & $(0.423)$ & (o.319) & $(0.265)$ & $(0.333)$ \\
\hline-0.228 & -0.503 & -0.279 & -0.283 & $-0.773^{* *}$ & -0.180 \\
\hline (o.539) & $\left(0.5^{28}\right)$ & $(0.551)$ & $(0.408)$ & (o.337) & $(0.432)$ \\
\hline $1.534^{*}$ & -0.187 & 0.737 & 0.329 & 0.225 & $1.328^{* * *}$ \\
\hline (o.834) & (o.479) & $\left(0.5^{17}\right)$ & (0.444) & $(0.346)$ & $(0.504)$ \\
\hline
\end{tabular}


TABLE 1 Multinomial logistic regression results (cont.)

\begin{tabular}{llllll}
\hline National Identity & {$[\mathrm{a}]$} & 2005 & 2006 & 2007 & 2008
\end{tabular}

Mixed sCH ${ }^{[b]}$

Better RELS

Worse RELS

Same RELS ${ }^{[b]}$

Catholic

Protestant

No Religion ${ }^{[b]}$

N

Log Likelihood

Pseudo $\mathrm{R2}^{[\mathrm{d}]}$ o

$\begin{array}{ll}-0.392 & -0.049 \\ (0.331) & (0.314) \\ -0.417 & -0.470 \\ (0.565) & (0.511)\end{array}$

0 o

0 o

$-0.159$

(o.376)

0.126

(o.677)

o o

0.371

$-0.077$

(0.315)

$1.355^{*}$

(0.296)

(o.847)

o

0.968

(o.623)

o

[a] The reference category is: Northern Irish. ${ }^{[b]}$ This parameter is set to zero because it is redundant.

\begin{tabular}{lllll}
\hline & & 2005 & 2006 & 2007 \\
\hline National Identity & British & $29.7 \%$ & $26.6 \%$ & $26.5 \%$ \\
& Irish & $39.4 \%$ & $41.7 \%$ & $41.1 \%$ \\
& Northern Irish & $30.9 \%$ & $31.7 \%$ & $32.4 \%$ \\
Sex & Male & $41.5 \%$ & $41.8 \%$ & $41.6 \%$ \\
& Female & $58.5 \%$ & $58.2 \%$ & $58.4 \%$
\end{tabular}


2010

o

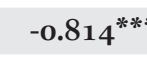

$-0.148$

2013

2014

2015

0.105

O

o

$\begin{array}{clc}0.024 & -0.059 & -0.006 \\ (0.224) & (0.183) & (0.235) \\ 0.305 & -0.072 & 0.312 \\ (0.355) & (0.383) & (0.473)\end{array}$

o

o

\begin{tabular}{|c|c|c|c|c|c|}
\hline $0.939^{* *}$ & $1.395^{* * *}$ & $1.309^{* * *}$ & $1.389^{* * *}$ & $1.161^{* * *}$ & $1.154^{* * *}$ \\
\hline$(0.381)$ & $(0.354)$ & (0.409) & $(0.271)$ & $(0.215)$ & $(0.283)$ \\
\hline$-2.769^{* * *}$ & $-1.828^{* * *}$ & $-1.942^{* *}$ & $-1.553^{* * *}$ & $-1.179^{* * *}$ & $-2.239^{* * *}$ \\
\hline (o.699) & $\left(0.55^{8}\right)$ & $(0.641)$ & $(0.436)$ & $(0.370)$ & (o.637) \\
\hline o & o & o & o & o & o \\
\hline
\end{tabular}

\begin{tabular}{rrrrrr}
\multicolumn{1}{l}{785} & \multicolumn{1}{c}{1422} & \multicolumn{1}{c}{1210} & \multicolumn{1}{c}{1364} & \multicolumn{1}{c}{1934} & \multicolumn{1}{c}{$115^{\circ}$} \\
539.895 & 692.962 & 648.100 & 749.117 & $1092.35^{8}$ & 648.844 \\
0.399 & 0.357 & 0.397 & 0.347 & 0.367 & 0.368
\end{tabular}

${ }^{[c]}$ Question not included in survey. ${ }^{[\mathrm{d}]}$ McFadden Pseudo R2. ${ }^{*} \mathrm{p}<.10 .{ }^{* *} \mathrm{p}<.05 .{ }^{* * *} \mathrm{p}<.01$.

\begin{tabular}{llllllll}
2008 & \multirow{2}{2}{ 2009 } & 2010 & 2011 & 2012 & 2013 & 2014 & 2015 \\
$26.2 \%$ & $29.3 \%$ & $28.2 \%$ & $27.1 \%$ & $33.0 \%$ & $29.7 \%$ & $28.6 \%$ & $24.8 \%$ \\
$42.3 \%$ & $38.8 \%$ & $40.9 \%$ & $37.0 \%$ & $37.1 \%$ & $38.5 \%$ & $38.5 \%$ & $36.7 \%$ \\
$31.4 \%$ & $31.9 \%$ & $30.8 \%$ & $35.8 \%$ & $29.9 \%$ & $31.8 \%$ & $32.9 \%$ & $38.5 \%$ \\
$39.4 \%$ & $39.1 \%$ & $36.4 \%$ & $45.1 \%$ & $41.8 \%$ & $42.8 \%$ & $41.1 \%$ & $41.6 \%$ \\
$60.6 \%$ & $60.9 \%$ & $63.6 \%$ & $54.9 \%$ & $58.2 \%$ & $57.2 \%$ & $58.9 \%$ & $58.4 \%$
\end{tabular}


TABLE 2 Summary statistics (cont.)

\begin{tabular}{|c|c|c|c|c|}
\hline & & 2005 & 2006 & 2007 \\
\hline \multirow[t]{3}{*}{ Residential Area (RES) } & Mainly Catholic & $32.1 \%$ & $33.2 \%$ & $30.0 \%$ \\
\hline & Mainly Protestant & $36.6 \%$ & $38.0 \%$ & $37.1 \%$ \\
\hline & Mixed & $31.3 \%$ & $28.9 \%$ & $32.9 \%$ \\
\hline \multirow[t]{5}{*}{ School (sCH) } & Mainly Protestant & $31.6 \%$ & $28.6 \%$ & $29 \cdot 7 \%$ \\
\hline & Mainly Catholic & $38.0 \%$ & $38.7 \%$ & $38.9 \%$ \\
\hline & Mostly Protestant & $16.0 \%$ & $15.2 \%$ & $16.8 \%$ \\
\hline & Mostly Catholic & $5.2 \%$ & $5 \cdot 7 \%$ & $4.3 \%$ \\
\hline & Mixed & $9.1 \%$ & $11.9 \%$ & $10.4 \%$ \\
\hline \multirow[t]{3}{*}{ Religion (REL) } & Catholic & $42.8 \%$ & $42.8 \%$ & $40.8 \%$ \\
\hline & Protestant & $40.9 \%$ & $40.2 \%$ & $37 \cdot 3 \%$ \\
\hline & No Religion & $16.3 \%$ & $17.0 \%$ & $21.9 \%$ \\
\hline Family's & Not Well Off & $4.5 \%$ & $4 \cdot 3 \%$ & $3.6 \%$ \\
\hline Socioeconomic & Not Very Well Off & $14.1 \%$ & $11.3 \%$ & $10.2 \%$ \\
\hline \multirow[t]{3}{*}{ Status (SES) } & Average & $55.0 \%$ & $54.9 \%$ & $58.9 \%$ \\
\hline & Well Off & $23.1 \%$ & $25 \cdot 7 \%$ & $24.8 \%$ \\
\hline & Very Well Off & $3 \cdot 4 \%$ & $3.8 \%$ & $2.5 \%$ \\
\hline \multirow{3}{*}{$\begin{array}{l}\text { Relations b/w Protestants } \\
\text { and Catholics (RELS) }\end{array}$} & Better & $48.2 \%$ & $51.3 \%$ & $64.0 \%$ \\
\hline & Worse & $13.0 \%$ & $12.3 \%$ & $8.2 \%$ \\
\hline & About the Same & $38.8 \%$ & $36.4 \%$ & $27.8 \%$ \\
\hline \multirow{4}{*}{$\begin{array}{l}\text { Socialize or Play Sports } \\
\text { with Others of Different } \\
\text { Religion (CONTACT) }\end{array}$} & Very Often & $27.1 \%$ & $\mathrm{~N} / \mathrm{A}$ & $32.6 \%$ \\
\hline & Sometimes & $27.1 \%$ & $\mathrm{~N} / \mathrm{A}$ & $27.0 \%$ \\
\hline & Rarely & $24.4 \%$ & $\mathrm{~N} / \mathrm{A}$ & $21.3 \%$ \\
\hline & Never & $21.3 \%$ & $\mathrm{~N} / \mathrm{A}$ & $19.1 \%$ \\
\hline
\end{tabular}

Ireland Young Life and Times Survey from 2005 through 2015 identify as Irish, 25 to 33 per cent identify as British, and 30 to 39 per cent identify as Northern Irish over the years 2005-15. Irish identifiers are overrepresented in the sample, but regardless the summary statistics show that young adults are divided among these three identity categories. 2015 was a high watermark as 38.5 per cent of the respondents self-identified as Northern Irish; this number might be an indicator of growing support for this third identity among this young constituency. Religious identification models the growing trend of secularization that has been persistent in the West over the last decades; while the percentage of those that identify as Catholic remains relatively stable at 40-44 percent, the 


\begin{tabular}{|c|c|c|c|c|c|c|c|}
\hline 2008 & 2009 & 2010 & 2011 & 2012 & 2013 & 2014 & 2015 \\
\hline $32.3 \%$ & $30.3 \%$ & $32.3 \%$ & $30.8 \%$ & $29.2 \%$ & $29.9 \%$ & $29.8 \%$ & $28.3 \%$ \\
\hline $32.4 \%$ & $36.1 \%$ & $33.0 \%$ & $33.5 \%$ & $34.1 \%$ & $35 \cdot 4 \%$ & $34.9 \%$ & $30.3 \%$ \\
\hline $35.2 \%$ & $33.6 \%$ & $34.7 \%$ & $35 \cdot 7 \%$ & $36.7 \%$ & $34.7 \%$ & $35 \cdot 3 \%$ & $41.4 \%$ \\
\hline $24.0 \%$ & $24.6 \%$ & $23.6 \%$ & $22.1 \%$ & $21.4 \%$ & $21.7 \%$ & $19 \cdot 7 \%$ & $19.1 \%$ \\
\hline $38.4 \%$ & $39.8 \%$ & $41.2 \%$ & $37.2 \%$ & $36.3 \%$ & $37.6 \%$ & $37 \cdot 7 \%$ & $36.8 \%$ \\
\hline $16.9 \%$ & $15 \cdot 5 \%$ & $16.2 \%$ & $18.1 \%$ & $18.5 \%$ & $17.9 \%$ & $20.9 \%$ & $20.5 \%$ \\
\hline $4.7 \%$ & $4.9 \%$ & $3 \cdot 3 \%$ & $6.1 \%$ & $7.6 \%$ & $5 \cdot 7 \%$ & $6.3 \%$ & $6.5 \%$ \\
\hline $16.1 \%$ & $15.2 \%$ & $15 \cdot 7 \%$ & $16.5 \%$ & $16.3 \%$ & $15.9 \%$ & $15.4 \%$ & $17.1 \%$ \\
\hline $43 \cdot 3 \%$ & $43.7 \%$ & $43.2 \%$ & $41.6 \%$ & $40.3 \%$ & $39.9 \%$ & $39.6 \%$ & $40.2 \%$ \\
\hline $40.4 \%$ & $37.1 \%$ & $37.6 \%$ & $36.2 \%$ & $37.1 \%$ & $33 \cdot 3 \%$ & $32.2 \%$ & $29.8 \%$ \\
\hline $16.2 \%$ & $19.2 \%$ & $19.2 \%$ & $22.2 \%$ & $22.6 \%$ & $26.9 \%$ & $28.2 \%$ & $30.0 \%$ \\
\hline $4 \cdot 7 \%$ & $5.0 \%$ & $4 \cdot 3 \%$ & $4.2 \%$ & $5 \cdot 3 \%$ & $4.8 \%$ & $4 \cdot 3 \%$ & $3.5 \%$ \\
\hline $12.1 \%$ & $13.2 \%$ & $14.3 \%$ & $15 \cdot 4 \%$ & $14.0 \%$ & $12.5 \%$ & $10.7 \%$ & $11.3 \%$ \\
\hline $58.2 \%$ & $57.2 \%$ & $57.1 \%$ & $58.0 \%$ & $56.4 \%$ & $54.2 \%$ & $54.2 \%$ & $53.7 \%$ \\
\hline $23.5 \%$ & $23.3 \%$ & $21.6 \%$ & $21.3 \%$ & $22.5 \%$ & $26.4 \%$ & $27.4 \%$ & $28.4 \%$ \\
\hline $1.5 \%$ & $1.2 \%$ & $2.6 \%$ & $1.1 \%$ & $1.9 \%$ & $2.1 \%$ & $3.6 \%$ & $3.1 \%$ \\
\hline $73.6 \%$ & $61.1 \%$ & $58.6 \%$ & $67.6 \%$ & $57.8 \%$ & $48.7 \%$ & $56.0 \%$ & $51.9 \%$ \\
\hline $3.8 \%$ & $7.8 \%$ & $8.4 \%$ & $3.9 \%$ & $6.4 \%$ & $12.2 \%$ & $6.1 \%$ & $6.3 \%$ \\
\hline $22.6 \%$ & $31.1 \%$ & $33.0 \%$ & $28.5 \%$ & $35.8 \%$ & $39.0 \%$ & $37.9 \%$ & $41.8 \%$ \\
\hline $\mathrm{N} / \mathrm{A}$ & $27.8 \%$ & $\mathrm{~N} / \mathrm{A}$ & $37.0 \%$ & $31.6 \%$ & $46.4 \%$ & $36.5 \%$ & $38.9 \%$ \\
\hline $\mathrm{N} / \mathrm{A}$ & $31.7 \%$ & $\mathrm{~N} / \mathrm{A}$ & $30.7 \%$ & $30.2 \%$ & $26.1 \%$ & $28.7 \%$ & $30.1 \%$ \\
\hline $\mathrm{N} / \mathrm{A}$ & $26.3 \%$ & $\mathrm{~N} / \mathrm{A}$ & $19.5 \%$ & $24.2 \%$ & $15 \cdot 5 \%$ & $18.9 \%$ & $19.0 \%$ \\
\hline $\mathrm{N} / \mathrm{A}$ & $14.2 \%$ & $\mathrm{~N} / \mathrm{A}$ & $12.8 \%$ & $14.0 \%$ & $12.0 \%$ & $15 \cdot 9 \%$ & $12.0 \%$ \\
\hline
\end{tabular}

percentage of those that identify as Protestant has declined from 41 per cent to 30 per cent, and the percentage of non-affiliated has risen from 16 per cent to 30 per cent. The number of young adults whose religion is Catholic remains consistent where their Protestant counterparts has seen religious identification decline since 2013. Over half of the respondents self-describe as middle class; 54-59 per cent of young adults in the sample consider their families' finances to be average or middle class. 21-27 per cent describe their families' socioeconomic status "as well off" or upper middle class and very few see their families as among the poorest or among the richest. 
The summary statistics point to more integration among the youth in Northern Ireland. There is a rise in the number of young people who live in mixed or integrated neighborhoods. Over the last ten years, there has been fluctuation in the numbers of those who live in predominately Catholic (2833 per cent) and Protestant (30-38 per cent) neighborhoods. In 2015, 41.4 per cent of 16 -year olds lived in integrated neighborhoods, and this percentage was a high watermark. Though more and more students are attending segregated schools according to the Northern Ireland Young Life and Times Survey, many still receive their education from mainly Catholic and Protestant educational institutions. In 2015, 17.1 per cent stated they attended an integrated school; the highest percentage of 16 -year olds in the survey's history. At the same time, the numbers over the last ten years highlight consistency among Catholic school attendees (36-41 per cent) and decline in Protestant school attendees (32-19 per cent). The majority of respondents believe relations between Protestant and Catholic communities have gotten better over the last ten years. The 16year olds in the sample are more optimistic about relations between the two communities with 2008 as a standout year. In 200874 per cent (the highest percentage in ten years) respondents felt relations were better, and 200548.2 per cent (the lowest percentage in ten years) respondents felt relations were better. Young adults socialize more often with different religious community with the lowest mark at 27 per cent in 2005 and the highest mark at 46 per cent in 2013. There is an overall decline among young adults that never socialize with outgroups and reached its lowest level of 12 per cent in 2015.

The results in Table 1 show both consistent and inconsistent support for our predicted hypotheses. Greater intergroup contact did not have a strong impact on identity choice. Socializing with others of different religious communities had a significant impact on national identity choice only for three years in the analysis- 2007, 2009, and 2015. ${ }^{7}$ The more young people interacted with others in 2007 the more British identity prevailed over the Northern Irish one. 16-years old are not impervious to the politics of the day and 2007 saw the return of the Northern Ireland Legislative Assembly after its suspension in 2002. The St. Andrews Agreement (2006) established a timetable that would restore devolved government in May 2007. In the March 2007 elections, the Democratic Unionist Party (DUP) and Sinn Féin won mandates to govern the Executive. Both the DUP and Sinn Féin masked the truth about negotiations in order to make the Agreement more palatable to their constituents. The DUP argued it forced Sinn Féin to recognize the legitimacy of institutions important to the Protestant unionist community such as the police and the constitutional

70.10 results are not discussed in the analysis but are included in Table 1. 
union with Britain, while Sinn Féin leadership did the same in regards to Irish reunification among its republican supporters (Cochrane 2013, p. 240). The same year the British military concluded its military operations in Northern Ireland, 'Operation Banner' after almost four decades. These two events showcased that Northern Ireland's place within the Union was secure.

Greater intergroup contact in 2009 was associated with more affinity for the Northern Irish identity over an Irish one. The year 2009 saw a marketed rise in dissident republican paramilitary activity. In January, a 300 pound bomb was found in Castlewellan, County Down near schools and homes with the Ballykinler army base as the alleged target (Moulton 2009). In March, Northern Ireland police officer, Stephen Paul Carroll was shot and killed at an army base in Craigavon, County Antrim (Allen and Bingham 2009). Two British Army soldiers, Patrick Azimkar and Mark Quinsey were killed in the Massereene Barracks and were the first soldiers to be killed in Northern Ireland since the 1997 ceasefire (Toolis 2009). A 400 pound car bomb partially exploded outside the Northern Ireland Policing Board and a 600 pound bomb was discovered in Forkhill, County Armagh (Sanders 2011, p. 242). Splinter republican groups opposed to the peace process took responsibility for these events. In May, Kevin McDaid, a Catholic community youth worker married to a Protestant was beaten to death outside of his home in the Heights area of Coleraine in an act of loyalist dissident violence (Black 2014). "The dissident threat was higher than at any time in the past five years" was a statement issued in May 2009 from the Independent Monitoring Commission, a watchdog organization on paramilitary activity (BBC News 2009). This rise in paramilitary activity led to 'Operation Dissent' in September 2009 that resulted in more patrols and checkpoints throughout Northern Ireland. The media reported on a new story of paramilitary violence, in particular republican paramilitary violence almost every month. In 2015, there was more preference for an Irish identity over a Northern Irish one. It could be argued that the year-long planning for the 100-year anniversary of the Easter Rising contributed. The Oireachtas and the Department of the Taoiseach launched a program to commemorate the events of 1916 in April 2015. Numerous media reports and documentaries were produced to reevaluate and reanalyze the Easter Rising that one would expect to impact the mentalities of young people in segregated schools and neighborhoods.

Attendance in an integrated versus non-integrated school has more influence on national identity preference than socialization with different communities. Unlike the coefficients for the CONTACT variable, the $\mathrm{SCH}$ variable is more consistent with the hypotheses. Those that attend a Protestant (controlled) school are no more likely to identify as British over Northern Irish, and 
those that attend a Catholic (maintained) school are more likely to choose an Irish identity over a Northern Irish one. The results in Table 1 illustrate that going to a Catholic school has much more of an effect on identity than attending a Protestant school. Events that happen outside of the classroom impact how students absorb, comprehend, and interpret the curriculum learned in the classroom even if the curriculum is the same for all students.

The only years where a Northern Irish identity was preferred over a British one was when a Catholic school was attended in 2007, 2013, and 2014. These years one could argue are years in Northern Ireland where Britishness was amplified. As discussed above, 2007 was a renewed year for the peace process as negotiations occurred between the two main parties, DUP and Sinn Féin and an agreement was forged between the two to share governing responsibilities in the Executive. This culminated in a historic photo between Ian Paisley and Gerry Adams. More so for British identity it solidified Northern Ireland as a part of the United Kingdom and shifted the promise of a united Ireland further out of reach. In December 2012 into 2013, riots broke out in East Belfast after the City Council decided to only fly the Union Jack flag 17 designated days out of the year instead of all year round. The compromise motion put forth by the Alliance Party was seen as an affront to unionist culture and identity (Cochrane 2013, p. 315). Cochrane (2013) states: "At a more mundane level, teenagers, and even children as young as ten and eleven, took part in 'recreational' violence in their local areas as a form of entertainment" (p. 316). The contentiousness of this period, one could argue would spill over into the classroom. Gerry Adams was arrested and held for questioning for four days in connection with the 30-year unsolved murder of Jean McConville in 2014. It would be over a year and a half before the Public Prosecution Service (PPS) would decide not to prosecute Gerry Adams or six others with the unsolved murder. This event would once again call into question the legacy of the Troubles, the peace process and the power-sharing government in Stormont (McAleese 2015). 2014 is also the 100-year anniversary of World War I (WWI) with commemorations all throughout the UK, a seminal event for unionists. Many soldiers from Northern Ireland served in the 36th Ulster Division and most known for their ultimate sacrifice two years later at the Battle of the Somme. "The Battle of the Somme became the archetype of Ulster's loyalty and defence of the crown" (Johnson 2003, p. 71). Learning about the historical significance of WWI, visual representations, and commemorations would heighten a sense of Britishness.

Attending an all-Catholic school elevated support for an Irish identity over a Northern Irish one. The only years that were not significant were 2005 and 2011. If one attends an all-Protestant school, it is more likely to lead to the adoption 
of a Northern Irish identity rather than an Irish one. The only years that were not significant were 2007 and 2009. The analysis seems to indicate all-Catholic schools are impediments to fomenting a Northern Irish identity. Students that attend mainly Protestant or mainly Catholic schools were not any more or any less likely to identify as British rather than Northern Irish than students at integrated schools. In 2005, 2008, and 2014 those attending a mostly Protestant school are more likely to identify as Northern Irish (compared to Irish) and in 2015 those attending a mostly Catholic school are more likely to identify as Irish (compared to Northern Irish). 2005 was the first time that power shifted from the Ulster Unionist Party and the Social Democratic and Labour Party to the Democratic Unionist Party and Sinn Féin in Northern Ireland and these two parties became the largest unionist and nationalist parties, two political parties in which the peace process and Northern Ireland's ultimate success would be attached to. In 2008, the global financial crisis hit the UK where some of its biggest banks had to be rescued with taxpayer funds (BBC News 2013); this economic crisis would be a threat to the financial stability of Northern Ireland and in particular its unionist majority. As stated above, WWI and the sacrifices associated with war are vital to a sense of Britishness and the Easter Rising and the sacrifices of the rebels are vital to a sense of Irishness. Seeing remnants of the past on walls, in murals, in commemorations coupled with learning about the rebellion would solidify these identities in these particular years.

Neighborhood composition has less effect on British identity than on Irish identity. For British identity (relative to Northern Irish identity), the coefficients are mostly in the hypothesized direction. In 2010, young people that live in a predominately Catholic neighborhood are more likely to adopt a Northern Irish identity over a British identity. 2007 and 2014 are the only significant years for Protestant neighborhoods. 2007 is an outlier in that respondents preferred a Northern Irish identity rather than British one compared to those in integrated neighborhoods. This outlier could be emblematic of the political situation of Northern Ireland in 2007 as elaborated above. As discussed above, 2014 is the 100-year anniversary of WWI, an event dear to the national identity of unionists. Commemorations throughout Northern Ireland and murals highlighting the sacrifices of individuals during the War would not be lost on 16-year olds in those neighborhoods.

Young adults that live in a predominately Catholic neighborhood are significantly more likely to identify and align themselves with an Irish identity, whereas those that live in a predominately Protestant neighborhood are more likely to reject an Irish identity. Claudine Gay (2004) reiterates that "residence in a predominantly black community may increase the likelihood that shared 
values and shared fate will be demonstrated and perceived" (p. 547). 2005 and 2010 were the only years where residence did not have an effect on Irish identity (relative to a Northern Irish one). Those that live in Protestant neighborhoods identify as Northern Irish at a significant level in 2007, 2010, 2011, and 2014 (relative to an Irish identity). Neighborhood composition has a greater impact on solidifying an Irish identity and preventing the construction of a Northern Irish identity. 2010 and 2011 saw numerous incidents of republican paramilitary violence. In October 2010, the Real IRA detonated a bomb in Derry with no causalities; this attack was one of forty strategic attacks throughout Northern Ireland. In April 2011, police officer Ronan Kerr was killed in Omagh by members of the Provisional IRA. And in June, the Ulster Volunteer Force (UVF) instigated riots between the Protestant residents of Newtownards Road in East Belfast and the Catholic residents of Short Strand (Cochrane 2013, pp. 270-1). At the same time that these events occurred, 2011 was the least violent year for paramilitary violence in Northern Ireland since statistics were collected in 1969 (Nolan 2012, p. 42). It was also the first full term of the Northern Ireland Legislative Assembly in 40 years. But at the same time in 2011, unemployment in the UK was at its highest level since 1996 and inflation reached five per cent (BBC News 2013).

Feelings about relations between the two communities have minimal influence on identity preference. Those that believe relations are worse than they were five years ago are more likely to identify as British rather than Northern Irish. In 2009, there was media report after media report about the rise in republican paramilitary activity throughout Northern Ireland targeting police officers and soldiers, fomenting fear in neighborhoods. The threat of dissident violence was higher than it had been in years. Feelings of threat and insecurity can cause a hardening of identity and in this case one could argue British identity. Individuals that believe relations are better between the two communities are more likely to choose a Northern Irish identity over an Irish one in 2010. In 2010, Sinn Féin and the DUP signed the Hillsborough Agreement, an agreement that devolved policing and criminal justice powers to the Northern Ireland Legislative Assembly. Gordon Brown, Prime Minister at the time remarked about the Agreement: "The achievements have been as great as they are inspirational. This moment and this agreement belongs to the people of Northern Ireland, all of the people, and now more than ever before so does their future ...This is the last chapter of a long and troubled story and the beginning of a new chapter after decades of violence, years of talks, weeks of stalemate" (McCaffery and Young 2010). This event was symbolic of a new path of stability and compromise for Northern Ireland, removed from the years of sectarianism and violence. 
The control variables have little effect on identity choice except for religion. Gender has almost no effect on identity preference. Only in 2015 are 16-year old young men more likely to prefer a British identity than their female counterparts. Gender had no impact on Irish identity choice. Socioeconomic status plays less of a role than believed. The higher the socioeconomic status of the family the likelihood that a young person identifies as Northern Irish rather than British but the significance is only at the 0.10 level for the years 2006, 2008, and 2015. The coefficients show that an Irish identity over a Northern Irish one is preferred as the financial status of the family increases. However, 2011 was the only year of significance (at the 0.05 level). Religion is a primary indicator of identity preference as expected. Catholic respondents reject a British identity every year except 2005 (but not significant) and prefer an Irish identity in every year of the model. Protestant respondents reject an Irish identity every year except 2005 and 2007 (but not significant), but are less likely to choose a British identity over a Northern Irish one. The only significant years where a British identity is chosen is 2011, 2012, and 2014. Where there is a strong correlation between Catholicism and Irishness, the link between Protestantism and Britishness is much weaker.

\section{Conclusion}

This work analyzes young adults' identity preferences and the factors that shape their identity choices post-Good Friday Agreement. We analyze the effects of intergroup contact and contextual effects while controlling for socioeconomic status, gender, and religion. The results show that intergroup contact is less impactful on identity choice. Interacting with diverse individuals and groups is no more likely to lead to the adoption of a Northern Irish identity. Contextual effects play more of a role in influencing identity choices. School and residential demographics had more impact on the solidification of Irish identity over a Northern Irish identity and less impact on British identity over a Northern Irish identity. The results align with previous research that highlights that Protestants are more likely to identify as Northern Irish as what it means to be British becomes more ambiguous and as cynicism grows among young people about British identity post-the Troubles (Todd, O'Keefe, Rougier, and Cañás Bottos 2006). The results show that when Northern Ireland is not inundated with violence and instead politically stable choosing a Northern Irish identity is preferred over a British identity. News articles have pointed to the openness of unionist supporters and politicians to the Northern Irish label as the day-to-day violence of the Troubles has subsided. Our results indicate that 
those that identify as Protestant, go to predominant Protestant schools, or live in majority Protestant neighborhoods are more prone to identify as Northern Irish than their Catholic counterparts.

Previous works shows that there is stronger ethno-national consciousness among minorities which could explain why school and neighborhood composition have more effect on Irish identity. Catholic/Irish identity seems to be more salient if we compare it to that of previous works on minority racial identity. "The influence of neighborhood quality on the salience of race is evidence of the material roots of black racial identity. It is because African-American beliefs about race are strongly informed by a legacy of economic oppression, and as such have a distinct economic component (as opposed to being strictly an expression of cultural solidarity), that actual exposure to material deprivation impacts the salience of race" (Gay 2004: p. 559). Socioeconomic inequality still persist post-Good Friday Agreement as Catholics remain on average less well off, underrepresented in higher-paid occupations, and more likely to be unemployed (Russell 2004). This reality has the consequence of hardening the saliency of an Irish identity. We believe that identity is more salient for those who perceive themselves as part of a minority and disenfranchised community, meaning holding on to Irish identity (and what it means to be Irish) is a lot more important and central to Irishness than to British identity (and what it means to be British). Also it could be that an Irish identity and the cultural features associated with it (like the Gaelic language) are more acceptable in a post-Good Friday Agreement environment, hence strengthening the steadfastness to Irish identity (Hayes and McAllister 2009).

Of all the controls, religion is the strongest indicator of national identity preference. Catholics prefer an Irish identity, and Protestants reject an Irish identity but at the same time do not significantly embrace a British identity over a Northern Irish one. The dependent variable does not assess how these identity categories are defined and does not address how respondents view what it means to be British, Irish, or Northern Irish. Future research will explore the meanings behind these identity categories. Future research will also explore how school curriculum shapes national identity and the propensity to adopt a Northern Irish identity. We plan to explore this through primary data collection because we believe education is an important component to national identity formation. This work has important implications about the future of these identity categories and specifically that of the Northern Irish identity as an inclusive identity choice for all Northern Irish young adults. The generations who grew up during the Troubles will become less relevant and this generation of young people with their lack of direct contact with the conflict and 
their increasing connections with the outside world through immigration, globalization, and media are the ones that will be shaping the future of Northern Ireland and its national identity going forth.

\section{References}

Allen, Nick and John Bingham. 10 March 2009. "Policeman Murdered in Northern Ireland Named as Stephen Carroll." http://www.telegraph.co.uk/news/uknews/ northernireland/4966664/Policeman-murdered-in-Northern-Ireland-named-asStephen-Carroll.html (accessed 3 January 2017).

Allport, Gordon W. 1954. The Nature of Prejudice. Cambridge: Addison Wesley.

ARK. 2016. Northern Ireland Life and Times Survey, 2015. http://www.ark.ac.uk/ nilt/2015/ (accessed 17 December 2016).

Barton, Keith C. and Alan W. McCully. 2005. "History, Identity, and the School Curriculum in Northern Ireland: An Empirical Study of Secondary Students' Ideas and Perspectives." Journal of Curriculum Studies 37 (1): 85-116.

Blalock, Hubert M. 1967. Toward a Theory of Minority-Group Relations. New York: Wiley. Barrett, Martyn and Louis Oppenheimer. 2011. "Findings, Theories and Methods in the Study of Children's National Identifications and National Attitudes." European Journal of Developmental Psychology 8 (1): 5-24.

ввс News. 19 September 2009. "PSNI Step Up Dissident Crackdown." ввс News http://news.bbc.co.uk/2/hi/uk_news/northern_ireland/8263983.stm (accessed 20 December 2016).

ввC News. 25 April 2013. "Uк Economy: The Story of the Downturn." ввс News http:// www.bbc.com/news/business-22283940 (accessed 22 December 2013).

ввС News. 7 May 2016. "Northern Ireland 2016 Election Results." ввс News http://www .bbc.com/news/election/2016/northern_ireland/results (accessed 14 January 2017).

Black, Rebecca. 16 May 2014. "Kevin McDaid Murder: Beaten to Death ... Five Years on Family Still Wait to See His Killers in Court." Belfast Telegraph http://www .belfasttelegraph.co.uk/news/northern-ireland/kevin-mcdaid-murder-beatento-death-five-years-on-family-still-wait-to-see-his-killers-in-court-30278410.html (accessed 10 October 2016).

Byrne, Jonny, Mary Conway, and Malcolm Ostermeyer. 2005. Young People's Attitudes and Experiences of Policing, Violence and Community Safety in North Belfast. Belfast: Northern Ireland Policing Board.

Cairns, Ed. 1982. "Intergroup Conflict in Northern Ireland." Pp. 277-298 in Social Identity and Intergroup Relations, edited by H. Tajfel. Cambridge: Cambridge University Press. 
Cassidy, Clare and Karen Trew. 2004. "Identity Change in Northern Ireland: A Longitudinal Study of Students' Transition to University." Journal of Social Issues 60 (3): 523-540.

Cochrane, Feargal. 2013. Northern Ireland: The Reluctant Peace. London: Yale University Press.

Department of Education of Northern Ireland. 2015. https://www.deni.gov.uk/ (accessed 4 October 2015).

Ewart, Shirley and Dirk Schubotz. 2004. Voices behind the Statistics: Young People's Views of Sectarianism in Northern Ireland. National Children's Bureau. http://webarchive .proni.gov.uk/20101005163454/http://www.ofmdfmni.gov.uk/voices.pdf.

Gallagher, Elizabeth and Ed Cairns. 2011. "National Identity and In-Group/Out-Group Attitudes: Catholic and Protestant Children in Northern Ireland." European Journal of Developmental Psychology 8 (1): $5^{8-73}$.

Gay, Claudine. 2004. "Putting Race in Context: Identifying the Environmental Determinants of Black Racial Attitudes." American Political Science Review 98 (4): 547-562.

Gellner, Ernest. 1983. Nations and Nationalism. Ithaca: Cornell University Press.

Giles, Micheal and Arthur Evans. 1985. "External Threat, Perceived Threat, and Group Identity." Social Science Quarterly 66: 50-66.

Glaser, James M. 1994. "Back to the Black Belt: Racial Environment and White Racial Attitudes in the South." Journal of Politics 56: 21-41.

Good Friday Agreement. 1998. https:/www.gov.uk/government/uploads/system/ uploads/attachment_data/file/136652/agreement.pdf.

Gordon, David. 26 March 2007. "Sinn Féin and Dup Strike Power-Sharing Deal." Belfast Telegraph http://www.belfasttelegraph.co.uk/news/sinn-fein-and-dup-strikepowersharing-deal-28396738.html (accessed 5 November 2015).

Gurin, Patricia, Arthur H. Miller, and Gerald Gurin. 1980. "Stratum Identification and Consciousness." Social Psychology Quarterly 43 (1): 30-47.

Harris, David. 1995. "Exploring the Determinants of Adult Black Identity: Context and Process." Social Forces 74 (1): 227-241.

Hayes, Bernadette C. and Ian McAllister. 2009. "Religion, Identity and Community Relations among Adults and Young Adults in Northern Ireland." Journal of Youth Studies 12 (4): 385-403.

Hayes, Bernadette C., Ian McAllister, and Lizanne Dowds. 2007. "Integrated Education, Intergroup Relations, and Political Identities in Northern Ireland." Social Problems $54(4): 454-482$.

Hogg, Michael A. 2001. "A Social Identity Theory of Leadership." Personality and Social Psychology Review 5 (3): 184-200.

Johnson, Nuala. 2003. Ireland, the Great War and the Geography of Remembrance. Cambridge: Cambridge University Press. 
Kula, Adam. 23 March 2016. "Integrated Education: Ni Public Wants Single School System, Poll Finds." Belfast Telegraph http://www.newsletter.co.uk/news/northernireland-news/integrated-education-ni-public-wants-single-school-system-pollfinds-1-7291508 (accessed 30 March 2016).

Mac Ginty, Roger and Pierre du Toit. 2007. “A Disparity of Esteem: Relative Group Status in Northern Ireland after the Belfast Agreement." Political Psychology 28 (1): 13-32.

Malešević, Sinisa. 2014. "Irishness and Nationalisms." Irish Journal of Sociology 22 (1): 130-142.

McGrath, F. C. 2012. "Settler Nationalism: Ulster Unionism and Postcolonial Theory." Irish Studies Review 20 (4): 463-485.

McAleese, Deborah. 29 September 2015. "Family of Jean McConville Will Continue to Seek Justice 'No Matter How Long It Takes." Belfast Telegraph http://www .belfasttelegraph.co.uk/news/northern-ireland/family-of-jean-mcconville-willcontinue-to-seek-justice-no-matter-how-long-it-takes-31567488.html (accessed 20 December 2016).

McAleese, Deborah. 20 October 2015. "50-50 Policy Could be Reintroduced as PSNI Battles to Attract Catholics." Belfast Telegraph http://www.belfasttelegraph.co.uk/ news/northern-ireland/5050-policy-could-be-reintroduced-as-psni-battles-toattract-catholics-34123056.html (accessed 14 January 2017).

McAlister, Siobhán., Deena Haydon, and Phil Scraton. 2013. "Violence in the Lives of Children and Youth in "Post-Conflict" Northern Ireland." Children, Children, Youth and Environments 23 (1):1-22.

McAlister, Siobhán, Phil Scraton, and Deena Haydon. 2009. Childhood in Transition: Experiencing Marginalisation and Conflict in Northern Ireland. Belfast: Save the Children.

McCaffery, Steven and David Young. 5 February 2010. "Belfast Violence Flares Again as Police Attacked." The Independent http://www.independent.co.uk/news/uk/homenews/transfer-of-policing-and-justice-powers-confirmed-1890330.html (accessed 20 December 2016).

McEvoy, Siobhán. 2000. "Communities and Peace: Young Catholics in Northern Ireland." Journal of Peace Research 37 (1): 85-103.

McGrellis, Sheena. 2010. "In Transition: Young People in Northern Ireland Growing up in, and out of, Divided Communities." Ethnic and Racial Studies 33 (5): 761-778.

McKeown, Shelley. 2013. Identity, Segregation and Peace-Building in Northern Ireland: A Social Psychological Perspective. New York: Palgrave MacMillan.

McKittrick, David. 1999. Lost Lives: The Stories of the Men, Women, and Children Who Died as a Result of the Northern Ireland Troubles. Edinburgh: Mainstream.

Northern Ireland Statistics and Research Agency. “2011 Census.” 27 March 2011. http:// www.nisra.gov.uk/census/2011/results.html (accessed 10 January 2016). 
Moulton, Emily. 02 February 2009. "Hugh Car Bomb Left Near School and Houses Branded Reckless, Callous and Contemptible." Belfast Telegraph http://www.bel fasttelegraph.co.uk/news/huge-car-bomb-left-near-school-and-houses-brandedreckless-callous-and-contemptible-28464764.html (accessed 3 January 2017).

Muldoon, Orla T., Karen Trew, JenniferTodd, Nathalie Rougier, and Katrina McLaughlin. 2007. "Religious and National Identity after the Belfast Good Friday Agreement." Political Psychology 28 (1): 89-103.

Nolan, Paul. o7 February 2012. "The Northern Ireland Peace Monitoring Report: Number One." http://cain.ulst.ac.uk/events/peace/docs/nipmr_2012-02.pdf.

Northern Ireland Statistics and Research Agency. "2001 Census.” 29 April 2001. http:// www.nisra.gov.uk/census/2001/results.html (accessed 10 January 2016).

O'Toole, Emer. 26 January 2013. "Why Can't Great Britain Look Northern Ireland in the Eye?" The Guardian https:/www.theguardian.com/commentisfree/2013/jan/25/ great-britain-northern-ireland-belfast-rioting (accessed 14 January 2017).

Pampel, Fred C. 2000. Logistic Regression: A Primer (Quantitative Applications in the Social Sciences). Thousand Oaks: Sage Publications.

Pettigrew, Thomas F. 1959. "Regional Differences in Anti-Negro Prejudice." Journal of Abnormal and Social Psychology 59: 28-36.

Pettigrew, Thomas F. and Linda R. Tropp. 2006. "A Meta-Analysis Test of Intergroup Contact Theory." Journal of Personality and Social Psychology 90 (5): 751-783.

Police Service of Northern Ireland. 2016. "Workforce Composition Statistics." https:// www.psni.police.uk/inside-psni/Statistics/workforce-composition-statistics/ (accessed 31 January 2017).

Russell, David. 2004. "Belfast: Strategies for a Shared City: Shared Space." Research Journal on Peace Conflict and Community Relations in Northern Ireland. Belfast: Community Relations Council.

Sanders, Andrew. 2011. Inside the IRA: Dissident Republicans and the War for Legitimacy. Edinburgh: Edinburgh University Press.

Scanlon, Michelle. 2008. "Which Comes First? Identity, Politics and Reconciliation in Northern Ireland." Quest Issue 7: 77-96 https:/www.qub.ac.uk/sites/QUEST/ FileStore/Issue7Mitchell/Filetoupload,146264,en.pdf.

Taggart, Peter and Nic Robertson. 07 January 2013. "Police: Extremist Group 'Orchestrating Violence' in Belfast over Union Jack." $c N N$ http://www.cnn.com/ 2013/01/o7/world/europe/northern-ireland-unrest/ (accessed12 November 2016).

Tajfel, Henri and John Turner. 1986. “The Social Identity Theory of Intergroup Behavior.” Pp. 7-24 in Psychology of Intergroup Relations, edited by S. Worchel and W. G. Austin, Chicago: Nelson-Hall Publishers.

Taylor, Donald M. and Fathali M. Moghaddam. 1994. Theories of Intergroup Relations: International Social Psychological Perspectives, 2nd Edition. New York: Praeger Publishers. 
Todd, Jennifer, Theresa O'Keefe, Nathalie Rougier, and Lorenzo Cañás Bottos. 2006. "Fluid or Frozen: Choice and Change in Ethno-national Identification in Contemporary Northern Ireland." Nationalism and Ethnic Politics 12 (3-4): 323-347.

Toolis, Kevin. o9 March 2009. "Massereene Barracks Shooting is Birth of New Republican Terrorism." The Telegraph http://www.telegraph.co.uk/news/4957989/ Massereeene-barracks-shooting-is-birth-of-new-republican-terrorism-KevinToolis.html (accessed 12 November 2015).

Trew, Karen, Orla Muldoon, Gary McKeown, and Katrina McLaughlin. 2009. "The Media and Memories of Conflict in Northern Ireland." Journal of Children and Media 3: 185-203.

Turner, John C., Penelope J. Oakes, S. Alexander Haslam, and Craig McGarty. 1994. "Self and Collective: Cognition and Social Context." Personality and Social Psychology Bulletin 20: 454-463.

Welch, Susan, Lee Sigelman, Timothy Bledsoe, and Michael Combs. 2001. Race and Place: Race Relations in an American City. New York: Cambridge University Press. 